DOI: $10.12731 / 2658-6649-2020-12-5-113-127$

UDC 577.12

\title{
ADAPTIVE PECULARITES OF CHLOROPHYLL CONTENT DYNAMICS IN PINUS SYLVESTRIS AND PICEA OBOVATA CONIFERS UNDER VEGETATION CONDITIONS IN THE SOUTH OF EASTERN SIBERIA
}

\section{Oskorbina M.V., Korotaeva N.E., Suvorova G.G.}

One of the most important factors in the study of photosynthesis is the state of the pigment Fund of the photosynthetic apparatus. Under different climatic and natural conditions, photosynthetic activity will tend to the maximum values. In the conditions of the South of Eastern Siberia, coniferous stands are most widespread, the stability and biological productivity of which directly depends on the realization of photosynthetic potential during the growing season.

The study presents the analysis of the dynamics of the content of photosynthetic apparatus pigments of common pine (Pinus sylvestris L.) and Siberian spruce (Picea obovata Ledeb.) at optimal moisture and unfavorable soil humidity during vegetation season. The material was selected at the experimental site located on the outskirts of Irkutsk (the territory of SIFIBR SB RAS).

The content of chlorophyll $a$ and $b$ in needles was determined using the SF 56 spectrophotometer in an extract with acetone during the vegetation periods under study. Photosynthetic uptake of carbon dioxide by needled shoots of the pine and spruce of the second year of lifespan was recorded by a multi-channel unit mounted on the basis of the IK gas analyzer "Infralyt-4". Two types of coniferous photosynthesis strategies are shown under different humidification conditions. It was found that under different conditions of soil moisture during the growing season in coniferous trees, the dynamics of chlorophyll content in light-harvesting complexes of photosystem II has several periods of increase.

Keywords: chlorophyll; light-harvesting complexes; photosynthetic apparatus; photosynthesis; adaptation; climatic factors; coniferous trees. 


\title{
АДАПТИВНЫЕ ОСОБЕННОСТИ ДИНАМИКИ СОДЕРЖАНИЯ ХЛОРОФИЛЛА В XВOE PINUS SYLVESTRIS И PICEA OBOVATA В УСЛОВИЯХ ВЕГЕТАЦИИ ЮГА ВОСТОЧНОЙ СИБИРИ
}

\author{
Оскорбина М.В., Коротаева Н.Е., Суворова Г.Г.
}

Одним из важнейтих факторов при изучении процесса фотосинтеза является состояние пигментного фонда фотосинтетического аппарата. При разных климатических и природных условиях фотосинтетическая активность будет стремиться к максимальным значениям. В условиях Юга Восточной Сибири наибольшее распространение имеют хвойные древостои, устойчивость и биологическая продуктивность которых напрямую зависит от реализации фотосинтетического потенциила 6 период вегетации. Материал отбирался на экспериментальном участке, заложенном на окраине г. Иркутска (территория СИФИБР СО РАН). Содержание хлорофилла а и $b$ в хвое определяли с помощью спектрофотометра СФ 56 (ЛОМО, Россия) в вытяжке с ацетоном в течение исследуемых вегетационных периодов. Фотосинтетическое поглощение углекислого газа охвоенными побегами второго года жизни сосны и ели регистрировали многоканальной установкой, смонтированной на основе ИК-газоанализатора «Infralyt-4». В исследовании представлен анализ динамики содержания пигментов фотосинтетического аппарата сосны обыкновенной (Pinus sylvestris L.) и ели сибирской (Picea obovata Ledeb.) в условиях оптимального увлажнения и неблагоприятного по уровню почвенной влажности периода вегетачии. Показань два типа стратегии фотосинтеза хвойных при различных условиях увлажнения. Установлено, что при различных условиях почвенного увлажнения периода вегетации у хвойных динамика содержания хлорофилла в светособирающих комплексах фотосистемы II имеет несколько периодов увеличения.

Ключевые слова: хлорофилл; светособираюшие комплексы; фотосинтетический аппарат; фотосинтез; адаптация; климатические фактоpы; хвойные.

\section{Introduction}

Photosynthesis is one of the most important physiological and biochemical processes occurring in the plant body. Complete transformation of energy in the 
process of photosynthesis is known to take place through five main protein complexes of the thylakoid membrane: PS I and PS II complexes, LHC cytochrome b6/f complex and membrane ATPase. The ratio of these complexes varies in the process of biogenesis of the photosynthetic apparatus $[1,2]$, as well as in the adaptation of plants to different light conditions [3]. Chl $a$ is known to be part of RC, LHC contains carotenoids, Chl $a$ and all Chl $b$. LHC and the PS II complex are mainly localized in the granule sections of the thylakoid membrane, while PS I and the mating complex are located in the contact zones of the membrane with the chloroplast matrix (in stromal thylakoids and end sections of granule thylakoids [1,4].

The stability of plant photosynthetic apparatus is formed through the change of concentration and redistribution of green and yellow pigments in LHC and / or RC of photosystems [5]. Chl $a$ is the main pigment of photosynthesis, its structure, biogenesis, and function have been studied in great detail. Chl $b$ is widely known to serve as an auxiliary light-harvesting pigment that captures and transmits light energy to the reaction centers of photosystems. It accounts for approximately $15-25 \%$ of the total chlorophyll content $[6,7]$. Chl $b$ is localized only in the light-accumulating complexes (LHC) of photosystems (LHC I and LHC II) and the small antenna of the photosystem (PS) II [8], in contrast to Chl $a$, which is a part of the crustal complexes of photosystems. In LHC I, Chl $b$ is about $22 \%$ of the total amount of chlorophylls, in LHC II - about $43 \%$, in the pigment-protein complex of the small antenna-31-46\% [4]. It has been shown that $\mathrm{Chl} b$ absorbs light in the short-wave region (425-475 nm), in which Chl $a$ weakly absorbs light. In this regard, Chl $b$ significantly increases light collection in low light conditions. Chl $b$ participates in the transfer of approximately $50 \%$ of the energy absorbed by carotenoids to Chl $a[9,10]$.

According to modern concepts, $\mathrm{Chl} a$ : $\mathrm{Chl} b$ ratio is higher at higher light exposure than at low light exposure, and the regulation of the Chl $b$ synthesis is important for the adaptation of plants to light of different intensity [11]. Chl $b$ acts as the main regulator of the antenna size of the photosynthetic apparatus: the binding of $\mathrm{Chl} b$ to LHC antenna proteins stabilizes it, and the initial catabolism reaction of $\mathrm{Chl} b$ activates a cascade of proteins that perform antenna disassembly. Since $\mathrm{Chl} b$ is concentrated only in the antenna, a decrease in the content of antenna proteins leads to a change in $\mathrm{Chl} a$ : $\mathrm{Chl} b$ ratio $[10,12]$.

Quantitative data on the content of photosynthetic pigments can be considered as a component of the ecological and physiological characteristics that make it possible, together with other parameters of functional activity, to identify the features of adaptation of the species that ensure successful existence of plants under extreme environmental conditions [13]. 
The influence of climatic conditions on the course of photosynthesis and the content of pigments has been reported $[14,15]$.

Southern regions of Eastern Siberia are characterized by special climatic conditions, such as high levels of solar radiation, cold winters, and insufficient soil moisture during summer vegetation period. Most of the territory is dominated by such coniferous species (Picea obovata and Pinus sylvestris) that demonstrate high resistance to low temperatures and biological productivity [14]. These conditions contribute to the formation of their special mechanisms of adaptation to specific growing conditions.

With this in view, the aim of the present work was to identify adaptive changes in the content of chlorophylls and PSA LHC in needles of common pine (Pinus sylvestris L.) and Siberian spruce (Picea obovata Ledeb.) due to photosynthetic productivity during vegetation periods with different climatic conditions.

\section{Research materials and methods}

The material was selected at the experimental site located on the outskirts of Irkutsk (the territory of SIFIBR SB RAS). Needle samples were taken from the middle part of the crowns of three trees of each species.

The content of chlorophyll $a$ and $b$ in needles was determined using the SF 56 spectrophotometer (LOMO, Russia) in an extract with acetone [16, p. 154] during the vegetation periods under study. The samples were taken from the middle part of the crowns of three trees of each species. The proportion of chlorophylls included in light-harvesting complexes (LHC) from the total amount of green pigments was calculated taking into account the fact that all $\mathrm{Chl} b$ is in LHC and the ratio of chlorophylls $a / b$ in LHC is 1.2 [17]. During all the years of observation, the arithmetic mean of the pigment content from 9 samples was calculated. The standard deviation calculated by Microsoft Excel 7.0 software varied within the range of \pm 0.01-0.08

Photosynthetic uptake of carbon dioxide by needled shoots of the pine and spruce of the second year of lifespan was recorded by a multi-channel unit mounted on the basis of the IK gas analyzer "Infralyt-4" [18]. Three trees of each species were used in the experiments. Needles monthly photosynthetic productivity was calculated as a product of multiplication of the average daily photosynthetic productivity determined by the number of experimental days by the number of days in the month. Annual photosynthetic productivity was calculated as the sum of photosynthetic productivity readings for all growing months. 
In parallel with studies of carbon dioxide gas exchange and pigment content, observations of environmental factors were made. The temperature in the assimilation chambers and outside air was recorded by a 12-point KSM recorder with copper thermal sensors. Air humidity was measured by a weekly hygrograph. The intensity of radiation over the canopy was measured by a Yanishevsky pyranometer with readings recorded by a KSP -4 potentiometer. Soil temperature at a depth of 5, 10, 15, $20 \mathrm{~cm}$ was measured by Savinov thermometers. Reserves of available soil moisture were determined by the thermostatic-weight method, taking samples every $10 \mathrm{~cm}$ in the upper $50 \mathrm{~cm}$ layer of the soil [19].

\section{Results and discussion}

These parameters were studied in the years of different moisture availability: 1 - with an extreme level of soil moisture and high air temperatures; and 2 - with a unique combination of high humidity and optimal air and soil temperatures.

To clarify the assumption that photosynthesis of conifers can be directly regulated by photochemical reactions, we studied the dependence of chlorophyll content on environmental factors and photosynthetic activity of needles. Dependence of biological productivity on the level of chlorophyll in cereal crops was previously demonstrated [20].

With this in view, dependence of changes in the content of chlorophyll on environmental factors and the water status of needles was analyzed. We previously found that under stressful conditions of soil drought, the dynamics of Chl $a$ in P. sylvestris correlated with changes in soil temperature (Fig. 1 - A), and in P. obovata - with the dynamics of total water content in conifers (Fig. 1 - B) [21]. At optimal soil moisture, the content of $\mathrm{Chl} b$ in conifers in both species reliably correlated with the dynamics of soil temperature (Fig. 1- C, D). There was no dependence of chlorophyll content dynamics on the needles water status.

As a result, the content of Chl $a$ in needles under stressful environmental conditions is regulated by the temperature status of the root system and the water status of needles.

The analysis of the dependence of maximum daily photosynthesis rate as an indicator of the photosynthetic potential realization on the content of chlorophyll in needles demonstrated that under stressful conditions of soil drought, the photosynthetic activity and the content of chlorophyll in P. sylvestris and $P$. obovata changed unidirectionally (Fig.2): the dynamics of photosynthesis is more consistent with chlorophyll $a\left(\mathrm{R}^{2}=0.62-0.65\right)$ (Fig. $\left.2 \mathrm{~A}, \mathrm{C}\right)$. At optimal soil moisture, there is no correlation of photosynthetic activity with chlorophyll content in the needles $\left(\mathrm{R}^{2}=0,14-0,29\right)$ (Fig. $\left.2 \mathrm{~B}, \mathrm{D}\right)$. 

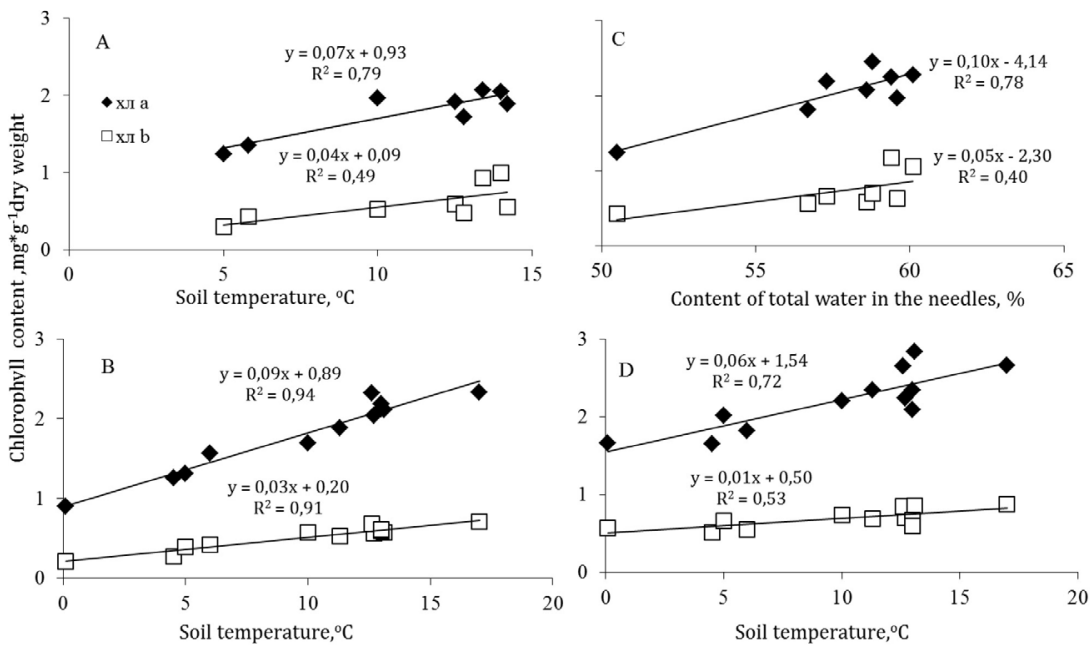

Fig. 1. Dependence of the content of $\mathrm{Chl} a$ and $\mathrm{b}$ in conifers of $\mathrm{P}$. sylvestris $(\mathrm{A}, \mathrm{B})$ and $\mathrm{P}$. obovata $(\mathrm{C}, \mathrm{D})$ on the water content in needles and soil temperature under stressful conditions $(\mathrm{A}, \mathrm{C})$ and optimal moisture $(\mathrm{B}, \mathrm{D})$.

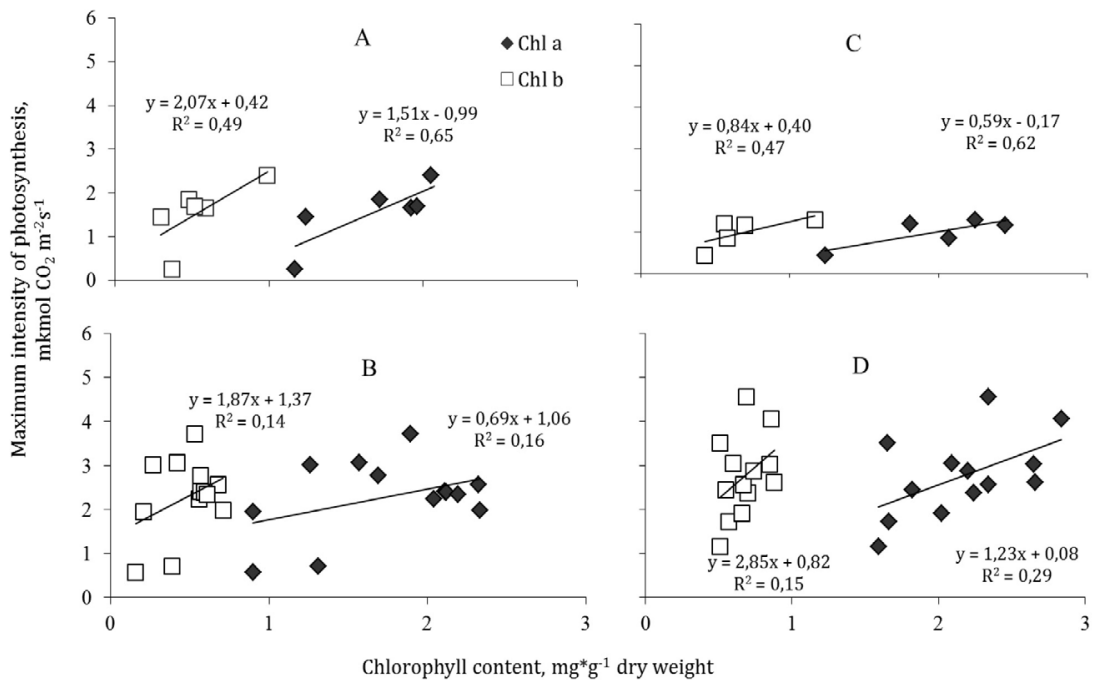

Fig. 2. Dependence of changes in the maximum daily photosynthesis intensity on the content of chlorophyll in $\mathrm{P}$. sylvestris $(\mathrm{A}, \mathrm{B})$ and $\mathrm{P}$. obovata $(\mathrm{C}, \mathrm{D})$ under drought conditions $(\mathrm{A}, \mathrm{C})$ and optimal moisture $(\mathrm{B}, \mathrm{D})$. 
Thus, in dry years, conifers show direct regulation of photosynthesis: spruce: water regime-chlorophyll (a) - photosynthesis. In pine: soil temperature-chlorophyll (a) - photosynthesis. The pigment that perceives the external impact and transmits it to photosynthesis is Chl $a$. In optimal moisture years, the dynamics of Chl $a$ and $b$ is determined by the soil temperature and is not directly related to the dynamics of photosynthesis productivity. In this case, the pigments accepting external influence are both $\mathrm{Chl} a$ and the necessary component of LHC is Chl $b$.

We found that for both P. sylvestris and P. obovata, the highest values of Chl $a$ were observed during the vegetation season with high photosynthetic productivity, and the highest values of $\mathrm{Chl} b$ were observed under stressful conditions. At the same time, the dynamics of chlorophyll content in LHC in these years was different: under stressful conditions, it had three maxima (periods of content increase) in P. sylvestris (Fig.3 A, B) and two in P. obovata (Fig. 3 C, D): in April, July-August and October. The first maximum of chlorophyll content in LHC is most likely due to the protection of the photosynthetic apparatus from the negative effects of high radiation levels and low temperatures during this period. The second period of increase in chlorophyll content in LHC is observed in both species during the maximum total content of Chl $(a+b)$ and is probably associated with the restructuring of the PSA at temperature optimum. The third period of chlorophyll content increase in LHC in P. sylvestris may indicate preparation of the photosynthetic apparatus to winter and enhancement of light collection function due to two-threefold reduction of light levels high enough level of photosynthesis maintained.

During the vegetation season with a high level of photosynthetic productivity (Fig. 3), the dynamics of the chlorophyll content in LHC has no pronounced and statistically reliable maxima. Thus, LHC maxima reflect PSA response to stressful conditions. When comparing photosynthetic productivity with the dynamics of chlorophyll content in LHC, we did not find a direct relationship between them.

The analysis of long-term experimental data showed that the character of chlorophyll content dynamics in LHC is reproduced and we see two or three periods of chlorophyll content increase in LHC in unproductive years with photosynthesis depression (Fig. 4). It should be noted that over the past decade, there has been a decrease in seasonal photosynthetic productivity in conifers in the vegetation conditions under study due to climatic peculiarities (Fig. 5). These periods were characterized by insufficient soil moisture and air temperature and were considered to be unfavorable for photosynthetic activity of conifers in the South of Eastern Siberia. 

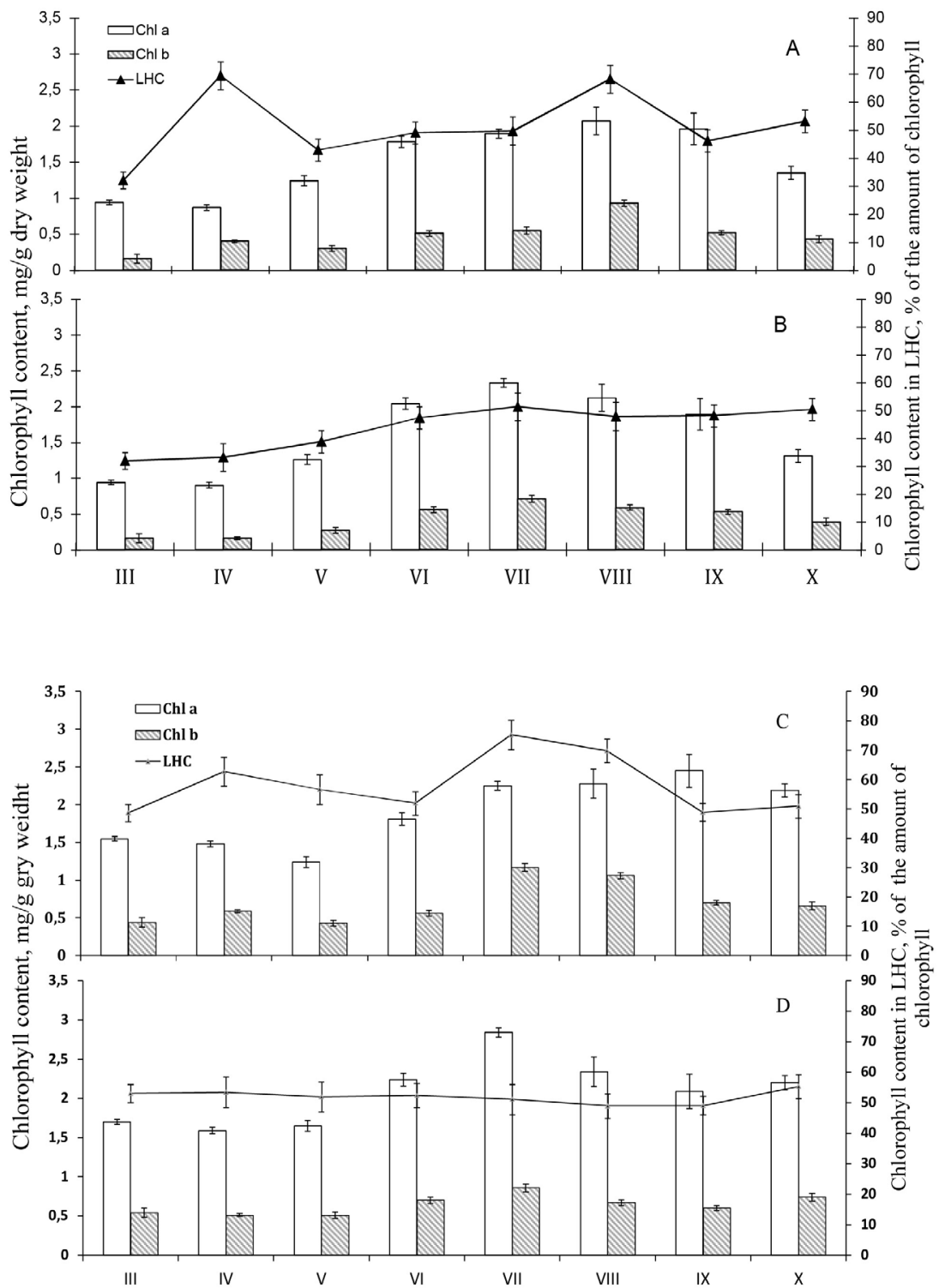

Fig. 3. Dynamics of chlorophyll and LHC content in P. sylvestris (A, B) and P. obovata $(C, D)$ needles under drought conditions $(A, C)$ and optimal soil moisture (B, D). 


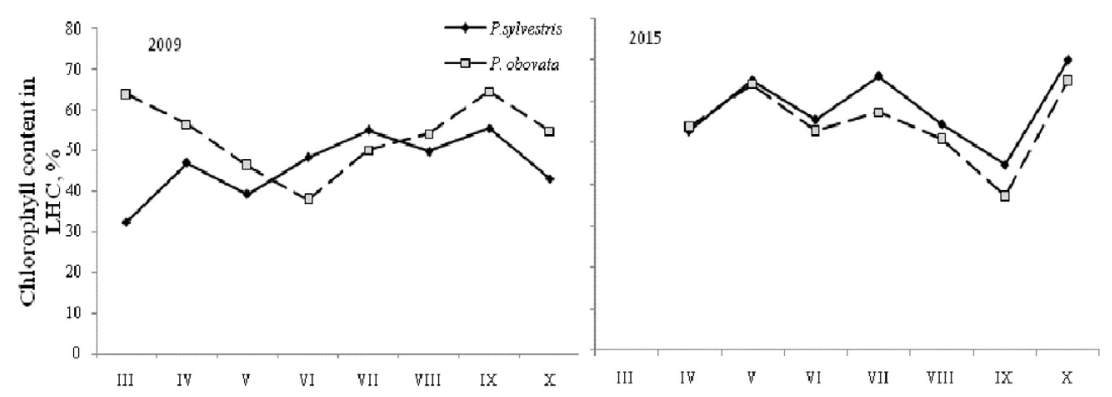

Fig. 4. Dynamics of chlorophyll content in pine and spruce LHCs during vegetation.

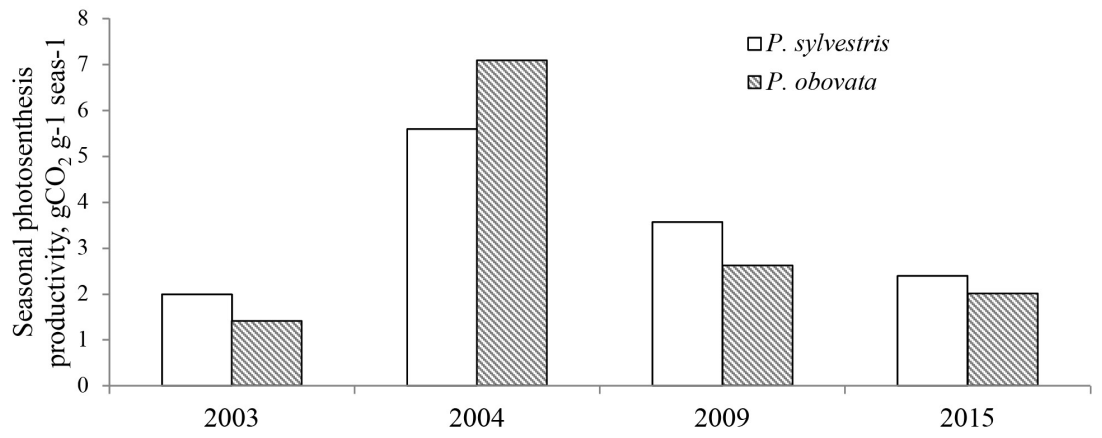

Fig. 5. Seasonal productivity of pine and spruce photosynthesis in different periods of vegetation.

The analysis suggests that under drought conditions, chlorophyll in LHC performs not only the function of light collection and thus regulation of photosystem activity, but also a protective function, which can be performed at the level of structural reorganization of thylakoids.

Recent studies have shown that mutant chloroplasts of barley seedlings and $A$. thaliana with impaired $\mathrm{Chl} b$ biosynthesis demonstrated impaired ability to form granules [3,22], and the nature of packaging of pigment-protein complexes in the granule membrane was changed. The ability to form granules was reduced because the content of integral LHC II proteins, which play a major role in stacking, decreased in the granule membranes [23]. The smaller size of the particles contributes to their denser packing in the granule membrane. At the same time, the lateral diffusion of photosynthetic proteins and low-molecular hydrophobic molecules, as well as the electron carrier in the photosynthetic electron transport chain of plastoquinone is limited [10]. 


\section{Conclusion}

In the South of Eastern Siberia, which is characterized by a high level of insolation throughout the vegetation season, regardless of climatic conditions, the photosynthetic apparatus will always have sufficient active radiation for high level of photosynthesis. In this regard, the content of chlorophyll in LHC will not limit the process of photosynthesis. Under these conditions, the greatest load in ensuring the optimal photosynthesis process will have RC FS, which consist of Chl $a$. Chl $b$ is known to be of great importance in the mechanisms of joining thylakoids into granules. It is $\mathrm{Chl} b$ that is one of the connecting links in the organization and stabilization of thylakoid membranes in grains. In this case, the participation of $\mathrm{Chl} b$ in LHC dynamics is most likely to have structural significance for the photosynthetic apparatus.

\section{Acknowledgments}

This work was performed using equipment belonging to the Bioanalitika Shared Instrumentation Center of the Siberian Institute of Plant Physiology and Biochemistry, Sibrian Branch, Russian Academy of Sciences, Irkutsk.

\section{References}

1. Rubin A. B., Krendeleva T. E. Reguliatsiia pervichnykh protsessov fotosinteza [Regulation of primary photosynthesis processes]. Biophysics, 2004, vol. 49, pp. 239-253.

2. Tyutereva E. V., Dmitrieva V. A., Voitsekhovskaya O. V. Hlorofill b kak istochnik signalov, regulirujushhih razvitie i produktivnost' rastenij [Chlorophyll b as a source of signals regulating the development and productivity of plants]. Agricultural biology, 2017, vol. 52, pp. 843-855. DOI: 10.15389/agrobiology.2017.5.843rus.

3. Lichtenthaler H.K. Biosynthesis, accumulation and emission of carotenoids, tocopherol, plastoquinone and isoprene in leaves under high photosynthetic irradiance. Photosynthesis Research, 2007, vol. 92, pp. 163-179. doi: 10.1007/ s11120-007-9204-y.

4. Voitsekhovskaja O.V., Tyutereva E.V. Chlorophyll b in angiosperms: functions in photosynthesis, signaling and ontogenetic regulation. Journal of Plant Physiology, 2015, vol. 189, pp. 51-64. doi: 10.1016/j.jplph.2015.09.013.

5. Bukhov N.G. Dynamic light regulation of photosynthesis, Plant Physiology, 2004, vol. 51, pp. 825-837. DOI: 10.1023/B:RUPP.0000047822.66925.bf.

6. Beale S.I. Enzymes of chlorophyll biosynthesis. Photosynthesis Research, 1999, vol. 60, pp. 43-73. https://doi.org/10.1023/A:1006297731456. 
7. Nakagawara E., Sakuraba Y., Yamasato A., Tanaka R., Tanaka A. Clp protease controls chlorophyll $\mathrm{b}$ synthesis by regulating the level of chlorophyllide a oxygenase. The Plant Journal, 2007, vol. 49, pp. 800-809. doi: 10.1111/j.1365313X.2006.02996.x.

8. Yamasato A., Nagata N., Tanaka R., Tanaka A. The N-terminal domain of chlorophyllide a oxygenase confers protein instability in response to chlorophyll $\mathrm{b}$ accumulation in Arabidopsis. The Plant Cell, 2005, vol. 17, pp. 1585-1597. doi: 10.1105/tpc.105.031518.

9. Formaggio E., Cinque G., Bassi R. Functional architecture of the major lightharvesting complex from higher plants. Journal of Molecular Biology, 2001, vol. 314, pp. 1157-1166. doi: 10.1006/jmbi.2000.5179.

10. Tyutereva E.V., Evkaikina A.I., Ivanova, A.N., Voitsekhovskaja O.V. The absence of chlorophyll $\mathrm{b}$ affects lateral mobility of photosynthetic complexes and lipids in grana membranes of Arabidopsis and barley chlorina mutants. Photosynthesis Research, 2017, vol. 113, pp. 357-370. DOI: 10.1007/s11120-017-0376-9.

11. Tanaka A., Ito H., Tanaka R., Tanaka N.K., Yoshida K., Okada K. Chlorophyll $a$ oxygenase (CAO) is involved in chlorophyll $b$ formation from chlorophyll a. Proceedings of the National Academy of Sciences, 1998, vol. 95, pp. 1271912723. https://doi.org/10.1073/pnas.95.21.12719.

12. Hoober J.K., Eggink L.L., Chen M. Chlorophylls, ligands and assembly of lightharvesting complexes in chloroplasts. Photosynthesis Research, 2007, vol. 94, pp. 387-400. DOI 10.1007/s11120-007-9181-1.

13. Shmakova N. Yu., Markovskaya, E. F. Photosynthetic pigments of plants and lichens of the Arctic tundra of Western Svalbard. Plant Physiology. 2010, vol. 57, pp. 819 - 825. DOI: 10.1134/S1021443710060038.

14. Suvorova G. G. Fotosintez hvojnyh derev'ev v uslovijah Sibiri [Photosynthesis of coniferous trees in Siberia]. Novosibirsk: Publishing house "Geo", 2009. $194 \mathrm{p}$.

15. Ivanova M.V., Suvorova G.G. Struktura i funkcija fotosinteticheskogo apparata hvojnyh v uslovijah juga Vostochnoj Sibiri [Structure and function of the photosynthetic apparatus of conifers in the South of Eastern Siberia]. Irkutsk: Publishing house of the Institute of Geography SB RAS, 2014. $102 \mathrm{p}$.

16. Shlyk A.A. Opredelenie hlorofillov i karotinoidov v jekstraktah zelenyh list'ev [Determination of chlorophylls and carotenoids in green leaf extracts] Biohimicheskie metody $v$ fiziologii rastenij [Biochemical methods in plant physiology]. Moscow: Nauka, 1971. 226 p.

17. Maslova T.G., Popova I.A. Adaptive properties of the plant pigment systems. Photosynthetica, 1993, vol. 29, pp. 195-203. 
18. Shcherbatyuk A. S., Rusakova L. V., Suvorova G. G., Yankova L. S. Uglekislotnyj gazoobmen hvojnyh Predbajkal'ja [Carbon Dioxide gas exchange of coniferous forests of the pre-Baikal region]. Novosibirsk: Nauka. Siberian branch, 1991. 135 p.

19. Fyodorovsky D.V. Metody opredelenija nekotoryh fizicheskih $i$ vodnyh svojstv pochvy, primenjaemye pri polevyh i vegetacionnyh opytah. Agrohimicheskie metody issledovanija pochv [Determination of water and physical properties of the soil during vegetation experiments. Agrochemical methods of soil research]. Moscow: Nauka, 1975. P. 296-330.

20. Andriyanova Y, Tarchevsky I. Hlorofill i produktivnost' rastenij [Chlorophyll and plant productivity]. Moscow: Nauka, 2000. 135 p.

21. Oskorbina M.V., Kopytova L.D., Suvorova G.G., Oskolkov V.A., Yankova L.S. Vlijanie klimaticheskih uslovij na dinamiku zelenyh pigmentov i fotosinteticheskuju produktivnost' hvojnyh [Influence of climatic conditions on the dynamics of green pigments and photosynthetic productivity of coniferous trees]. Vestnik KrasGAU, 2010, vol. 4, pp. 25-30.

22. Kim E.H., Li X.P., Razeghifard R., Anderson J.M., Niyogi K.K., Pogson B.J., Chow W.S. The multiple roles of light-harvesting chlorophyll a/b-protein complexes define structure and optimize function of Arabidopsis chloroplasts: a study using two 854 chlorophyll b-less mutants. Biochimica et Biophysica Acta, 2009, vol. 1787, pp. 973-984. doi: 10.1016/j.bbabio.2009.04.009.

23. Miller K.R., Miller G.J., McIntyre K.R. The light-harvesting chlorophyll-protein complex of photosystem II. Its location in the photosynthetic membrane. Journal of Cell Biology, 1976, vol. 71, pp. 624-638. doi: 10.1083/jcb.71.2.624.

\section{Список литературы}

1. Rubin A.B., Krendeleva T.E. Regulation of primary photosynthesis processes // Биофизика. 2004. vol. 49. pp. 223-237.

2. Тютерева Е.В., Дмитриева В.А., Войцеховская О.В. Хлорофилл b как источник сигналов, регулирующих развитие и продуктивность растений // Сельскохозяйственная биология. 2017. T. 52. с. 843-855. DOI: 10.15389/ agrobiology.2017.5.843rus.

3. Lichtenthaler H.K. Biosynthesis, accumulation and emission of carotenoids, tocopherol, plastoquinone and isoprene in leaves under high photosynthetic irradiance // Photosynthesis Research, 2007, vol. 92, pp. 163-179. doi: 10.1007/ s11120-007-9204-y.

4. Voitsekhovskaja O.V., Tyutereva E.V. Chlorophyll b in angiosperms: functions in photosynthesis, signaling and ontogenetic regulation // Journal of Plant Physiology, 2015, vol. 189, pp. 51-64. doi: 10.1016/j.jplph.2015.09.013. 
5. Bukhov N.G. Dynamic light regulation of photosynthesis // Plant Physiology, 2004, vol. 51, pp. 825-837. DOI: 10.1023/B:RUPP.0000047822.66925.bf.

6. Beale S.I. Enzymes of chlorophyll biosynthesis // Photosynthesis Research, 1999, vol. 60, pp. 43-73. https://doi.org/10.1023/A:1006297731456.

7. Nakagawara E., Sakuraba Y., Yamasato A., Tanaka R., Tanaka A. Clp protease controls chlorophyll $\mathrm{b}$ synthesis by regulating the level of chlorophyllide a oxygenase // The Plant Journal, 2007, vol. 49, pp. 800-809. doi: 10.1111/j.1365313X.2006.02996.x.

8. Yamasato A., Nagata N., Tanaka R., Tanaka A. The N-terminal domain of chlorophyllide a oxygenase confers protein instability in response to chlorophyll $\mathrm{b}$ accumulation in Arabidopsis // The Plant Cell, 2005, vol. 17, pp. 1585-1597. doi: $10.1105 /$ tpc. 105.031518 .

9. Formaggio E., Cinque G., Bassi R. Functional architecture of the major lightharvesting complex from higher plants // Journal of Molecular Biology, 2001, vol. 314, pp. 1157-1166. doi: 10.1006/jmbi.2000.5179.

10. б. Tyutereva E.V., Evkaikina A.I., Ivanova, A.N., Voitsekhovskaja O.V. The absence of chlorophyll $b$ affects lateral mobility of photosynthetic complexes and lipids in grana membranes of Arabidopsis and barley chlorina mutants // Photosynthesis Research, 2017, vol. 113, pp. 357-370. DOI: 10.1007/s11120017-0376-9.

11. Tanaka A., Ito H., Tanaka R., Tanaka N.K., Yoshida K., Okada K. Chlorophyll $a$ oxygenase (CAO) is involved in chlorophyll $b$ formation from chlorophyll $a$. // Proceedings of the National Academy of Sciences, 1998, vol. 95, pp. 1271912723. https://doi.org/10.1073/pnas.95.21.12719.

12. Hoober J.K., Eggink L.L., Chen M. Chlorophylls, ligands and assembly of lightharvesting complexes in chloroplasts // Photosynthesis Research, 2007, vol. 94, pp. 387-400. DOI 10.1007/s11120-007-9181-1.

13. Shmakova N. Yu., Markovskaya, E. F. Photosynthetic pigments of plants and lichens of the Arctic tundra of Western Svalbard // Plant Physiology. 2010, vol. 57, pp. 819 - 825. DOI: $10.1134 / \mathrm{S} 1021443710060038$.

14. Суворова Г.Г. Фотосинтез хвойных деревьев в условиях Сибири. Новосибирск: Академическое изд-во "Гео", 2009. 194 с.

15. Иванова М.В., Суворова Г.Г. Структура и функция фотосинтетического аппарата хвойных в условиях юга Восточной Сибири. Иркутск: Изд-во Ин-та географии им. В.Б. Сочавы СО РАН, 2014. 102 с.

16. Шлык А.А. Определение хлорофиллов и каротиноидов в экстрактах зеленых листьев // Биохимические методы в физиологии растений. М.: Наука, 1971. C. $154-169$. 
17. Maslova T.G., Popova I.A. Adaptive properties of the plant pigment systems // Photosynthetica, 1993, vol. 29, pp. 195-203.

18. Углекислотный газообмен хвойных Предбайкалья / Щербатюк А.С., Русакова Л.В., Суворова Г.Г., Янькова Л.С. Новосибирск: Наука. Сибирское отделение, 1991. 135 с.

19. Федоровский Д.В. Определение водных и физических свойств почвы при проведении вегетационных опытов / Агрохимические методы исследования почв. М.: Наука, 1975. С. 296-330.

20. Андриянова Ю., Тарчевский И. Хлорофилл и продуктивность растений М.: Наука, 2000. 135 с.

21. Влияние климатических условий на динамику зеленых пигментов и фотосинтетическую продуктивность хвойных / Оскорбина М.В, Копытова Л.Д., Суворова Г.Г., Осколков В.А., Янькова Л.С. // Вестник КрасГАУ. 2010. № 5. № 4. C. 25-30.

22. Kim E.H., Li X.P., Razeghifard R., Anderson J.M., Niyogi K.K., Pogson B.J., Chow W.S. The multiple roles of light-harvesting chlorophyll a/b-protein complexes define structure and optimize function of Arabidopsis chloroplasts: a study using two 854 chlorophyll b-less mutants // Biochimica et Biophysica Acta, 2009, vol. 1787, pp. 973-984. doi: 10.1016/j.bbabio.2009.04.009.

23. Miller K.R., Miller G.J., McIntyre K.R. The light-harvesting chlorophyll-protein complex of photosystem II. Its location in the photosynthetic membrane // Journal of Cell Biology, 1976, vol. 71, pp. 624-638. doi: 10.1083/jcb.71.2.624.

\section{DATA ABOUT THE AUTHORS}

Oskorbina Maria Vladimirovna, Cand. Sc. (Biology), Senior Researcher of the Laboratory of Ecosystems Bioindication

Siberian Institute of Plant Physiology and Biochemistry, Siberian Branch of Russian Academy of Sciences (SIPPB SB RAS)

132, Lermontov Str., Irkutsk, 664033, Russian Federation

omaria-84@yandex.ru

SPIN-code: 9865-6605

ORCID: 0000-0002-1100-9743

ResearcherID: M-6979-2016

Scopus Author ID: 56539389800

Korotaeva Natalya Eugenyevna, Cand. Sc. (Biology), Senior Researcher of the Laboratory of Physiological Genetics 
Siberian Institute of Plant Physiology and Biochemistry, Siberian Branch of Russian Academy of Sciences (SIPPB SB RAS)

132, Lermontov Str., Irkutsk, 664033, Russian Federation

knev73@yandex.ru

SPIN-code: 7696-3709

ORCID: 0000-0003-4236-389X

ResearcherID: I-5643-2018

Scopus Author ID: 6602401022

Suvorova Galina Georgievna, Dr. Sc., Lead Researcher of the Laboratory of Ecosystems Bioindication

Siberian Institute of Plant Physiology and Biochemistry, Siberian Branch of Russian Academy of Sciences (SIPPB SB RAS)

132, Lermontov Str., Irkutsk, 664033, Russian Federation

suvorova@sifibrirk.ru

SPIN-code: 6641-6878

ORCID: 0000-0002-8496-4995

ResearcherID: $S-7291-2016$

Scopus Author ID: 36998925700

\section{ДАННЫЕ ОБ АВТОРАХ}

Оскорбина Мария Владимировна, к.б.н., старший научный сотрудник лаборатории биоиндикации экосистем Сибирский институт физиологии и биохимии растений СО РАН ул. Лермонтова, 132, г. Иркутск, 664033, Российская Федераиия omaria-84@yandex.ru

Коротаева Наталья Евгеньевна, к.б.н., старший научный сотрудник лаборатории физиологической генетики Сибирский институт физиологии и биохимии растений СО РАН ул. Лермонтова, 132, г. Иркутск, 664033, Российская Федерачия knev73@yandex.ru

Суворова Галина Георгиевна, д.б.н., ведущий научный сотрудник лаборатории биоиндикации экосистем Сибирский институт физиологии и биохимии растений СО РАН ул. Лермонтова, 132, г. Иркутск, 664033, Российская Федераиия suvorova@sifibr.irk.ru 